Article

\title{
Presence of Shiga Toxin-Producing Escherichia coli (STEC) in Fresh Beef Marketed in 13 Regions of ITALY (2017)
}

\author{
Bianca Maria Varcasia, Francesco Tomassetti, Laura De Santis, Fabiola Di Giamberardino, \\ Sarah Lovari, Stefano Bilei and Paola De Santis * \\ Istituto Zooprofilattico Sperimentale Lazio e Toscana, “M. Aleandri”, 00178 Rome, Italy; \\ biancamaria.varcasia@izslt.it (B.M.V.); francesco.tomassetti@izslt.it (F.T.); laura.desantis@izslt.it (L.D.S.); \\ fabiola.digiamberardino@izslt.it (F.D.G.); sarah.lovari@izslt.it (S.L.); stefano.bilei@izslt.it (S.B.) \\ * Correspondence: paola.desantis@izslt.it; Tel.: +39-06-72596047
}

Received: 30 September 2018; Accepted: 5 December 2018; Published: 6 December 2018

\begin{abstract}
The aim of this study was to determine the prevalence of Shiga toxin-producing Escherichia coli in fresh beef marketed in 2017 in 13 regions of Italy, to evaluate the potential risk to human health. According to the ISO/TS 13136:2012 standard, 239 samples were analysed and nine were STEC positive, from which 20 strains were isolated. The STEC-positive samples were obtained from Calabria $(n=1)$, Campania $(n=1)$, Lazio $(n=2)$, Liguria $(n=1)$, Lombardia $(n=1)$ and Veneto $(n=3)$. All STEC strains were analysed for serogroups O26, O45, O55, O91, O103, O104, O111, O113, O121, O128, O145, O146 and O157, using Real-Time PCR. Three serogroups were identified amongst the 20 strains: O91 $(n=5), \mathrm{O} 113(n=2)$, and O157 $(n=1)$; the O-group for each of the 12 remaining STEC strains was not identified. Six stx subtypes were detected: stx $1 a$, st $x 1 c, s t x 2 a, s t x 2 b, s t x 2 c$ and st $x 2 d$. Subtype stx2c was the most common, followed by stx2d and stx2b. Subtype stx2a was identified in only one eae-negative strain and occurred in combination with stx $1 a$, stx $1 c$ and stx $2 b$. The presence in meat of STEC strains being potentially harmful to human health shows the importance, during harvest, of implementing additional measures to reduce contamination risk.
\end{abstract}

Keywords: Escherichia coli (STEC); beef; serogroups; stx-genes; stx-subtypes

\section{Introduction}

Shiga toxins (Stx) are potent cytotoxins encoded by lambdoid phages and integrated into the bacterial chromosome of a large and complex group of pathogenic Escherichia coli (STEC) strains that cause disease in humans [1,2]. Shiga toxins are immunologically distinct [3] and based on this antigenic diversity are divided into two groups, Stx1 and Stx2 [4]. Epidemiological studies [3-5] have shown that some Stx1 and Stx2 subtypes often are associated with severe human STEC illnesses [4]. Three Stx1 variants have been identified: Stx1a, Stx1c and Stx1d [2,4]. Usually, subtypes Stx1c and Stx1d are found in the meat of sheep, deer, and wildlife [6-9] and are rarely associated with disease in humans [2]. Subtypes Stx2a, Stx2b, Stx2c, Stx2d, Stx2e, Stx2f and Stx2g, along with the recently discovered Stx2h, are the eight Stx2 subtypes known to exist [4,10-14]. Subtypes Stx2a, Stx2c and Stx2d are associated with STEC infections in humans [11,15-17], while Stx2e, Stx2f, Stx2g are mainly found in animals $[2,10,11]$. Some studies have suggested that STEC strains producing Stx2f can cause diarrhoea in humans [18]; however, recently, STEC strains carrying the stx2f gene have been isolated from patients with hemolytic uremic syndrome (HUS) [18,19].

The majority of STEC strains associated with disease in humans possess adherence factors that facilitate their attachment to the intestinal epithelial cells [20]. The principal adherence factor is the 
intimin protein encoded by the eae gene, and responsible for what is known as the "attaching and effacing" (A/E) lesion of the intestinal mucosa [4,21-23]. The simultaneous presence of eae and st $x 2$ genes is considered a reliable indicator of a particular STEC strain's ability to cause severe disease in humans [24]. However, STEC strains that lack the eae gene can also cause severe disease by utilising alternative adherence mechanisms, as evidenced recently during a large outbreak of HUS in Germany in 2011 and caused by an enteroaggregative haemorrhagic Escherichia coli (EAHEC) O104:H4 carrying the $a g g R$ and aaiC genes in combination with stx2a [25].

Serological identification, based on the somatic $(\mathrm{O})$ and flagellar $(\mathrm{H})$ antigens, has to date resulted in the identification of $\sim 470$ STEC serotypes [8,26], all able to produce any one of the twelve known Stx subtypes or combinations of these subtypes [27]. The European Food and Safety Authority (EFSA) has identified STEC encoding the stx and eae genes that belong to serogroups O26, O103, O111, O145, O157, the so-called "big five", as those of major concern to human health in Europe [28]. Following the O104:H4 outbreak in Germany, this serotype was incorporated into the screening protocol for all eae-negative STEC isolated from food (Regulation EU No. 209/2013) [29].

STEC O157 is the most frequently reported serogroup worldwide [17,30,31]. The incidence of STEC O157 has however decreased in recent years, whereas the so-called non-O157 STEC serogroups are increasingly associated with haemorrhagic colitis (HC) and HUS in humans [27,31]; the most frequently encountered non-O157 serogroups are O26, O103, O111, O121, O145, O45, O118, O71 and O186 [31,32]. In 2015, as reported by EFSA and the European Centre for Disease Prevention (ECDC), in Europe, the STEC serogroups most commonly isolated from beef were O157 and O26, followed by O148, O145, O8, O113, O91, O130, O174 and O113. Many of these STEC serogroups were linked to human illnesses, confirming the epidemiological involvement of beef in STEC infections [33]. In 2016, in Europe, the STEC serogroup most frequently isolated from bovine meat was O157, followed by O113, O26, O145 and O174 [34]. In Italy, STEC O26 was the predominant serogroup in 2012 and responsible for about half of STEC cases in humans, followed by STEC O157 and STEC O111 [35]. In Europe, as a consequence of only a handful of countries doing any monitoring, few data exist on the isolation of STEC from beef $[1,21,34]$.

The main reservoirs of STEC are ruminants, including wildlife. STEC can colonize the gut asymptomatically, their excretion into the environment [21] serving as a significant route of infection in humans [3]. Other studies have demonstrated that the hides of cattle represent an important source of STEC, resulting in carcass contamination during harvest $[21,36]$. Transmission to cattle may take place on-farm or during transportation to the abattoir $[5,36]$. STEC prevalence in cattle appears to be influenced by the age of the animal, the season, and probably, also feed composition $[5,17]$. Pathways along which humans may become infected include faecal-oral contamination during harvest, direct contact with faeces, STEC cross-contamination and multiplication during the preparation and handling of animal-derived foodstuffs, and human-to-human transmission [21,37]. European legislation (Regulation EU No. 2073/2005 and its amendments Regulation EU No. 1441/2007) [38,39] did not include the screening of STEC from meat products because, originally, very few data were available on the health risks associated with STEC-contaminated food [1,21].

In 2012, the International Organisation for Standardisation (ISO) issued the ISO/TS 13136:2012 method for the detection of STEC with a focus on the st $x 1$ and st $x 2$ virulence genes and on the eae adhesion factor gene, as these are associated with the "big five" serogroups [40]. The method is based on the Real-Time PCR screening of enrichment cultures, followed by serogroup identification and characterisation of isolated strains. The initial enrichment step, by increasing concentrations of the target bacteria, not only enhances the sensitivity of the method but also ensures the viability of bacterial cells from which positive results are obtained [41]. To date, as stated in the ESFA and ECDC 2017 report on trends and sources of zoonoses, zoonotic agents and food-borne outbreaks, $91.5 \%$ of the samples tested during 2016 by the European Member States, were analysed using ISO/TS 13136:2012 [34]. Some studies have suggested that the culture conditions involving media formulations and incubation temperature, as currently recommended in the ISO, be modified to further enhance 
STEC growth [41-44]. While improvements to the current ISO standard are possible, food authorities will always promote the use of a standardized method so results from different countries remain comparable [34].

The aim of this study was to determine the prevalence of Shiga toxin-producing Escherichia coli in fresh beef marketed in 13 regions of Italy in 2017, to evaluate the potential risk to human health.

\section{Materials and Methods}

\subsection{Sampling}

Between January and December 2017, 239 samples of refrigerated fresh beef were obtained from the retail market in 13 regions of Italy. The samples were collected originally to monitor antimicrobial resistance in zoonotic bacteria from food-producing animals and meat, under Decision 2013/652/EC [45]. The antimicrobial resistance aspects do not form part of this study, but they provided us with the opportunity to assay samples that were representative of most of Italy. The 13 regions account for $>90 \%$ of the total animals harvested in Italy. The samples were arbitrarily chosen from supermarkets and traditional butcheries, and were obtained at least once monthly throughout the year to cover all four seasons. A single sample was collected from each lot of origin, either domestic or imported; frozen meat was excluded. The samples included meat either sliced or diced, vacuum-wrapped, or packaged under a controlled atmosphere. The 239 samples were obtained from the regions of Abruzzo $(n=8)$, Calabria $(n=7)$, Campania $(n=3)$, Emilia Romagna $(n=23)$, Friuli Venezia Giulia $(n=6)$, Lazio $(n=34)$, Liguria $(n=6)$, Lombardia $(n=53)$, Marche $(n=7)$, Piemonte $(n=25)$, Puglia $(n=22)$, Toscana $(n=20)$ and Veneto $(n=25)$.

\subsection{Screening of Enrichment Cultures}

The samples were analysed following the ISO/TS 13136:2012 standard [40]. Twenty-five grams of meat homogenised with $225 \mathrm{~mL}$ of modified Tryptone Soya Broth (mTSB) (Biolife Italiana srl, Milan, Italy) supplemented with $16 \mathrm{mg} / \mathrm{mL}$ of novobiocin (Biolife Italiana srl, Milan, Italy) and incubated at $37^{\circ} \mathrm{C}$ for $18-24 \mathrm{~h}$. DNA was extracted from $1 \mathrm{~mL}$ of each enrichment culture, using an automated nucleic acid purification system (MagPurix ${ }^{\circledR} 12 \mathrm{~S}$, Resnova, Rome, Italy), following the manufacturer's instructions. The extraction method provided approximately $100 \mathrm{ng} / \mu \mathrm{L}$ of DNA eluted in nuclease-free water at a final volume of $200 \mu \mathrm{L}$. DNA extracts were tested for the stx1, st $x 2$ and eae genes by Real-Time PCR, following the ISO standard procedure given above. PCR amplifications were done maintaining a final volume of $20 \mu \mathrm{L}$ that contained $3 \mu \mathrm{L}$ of DNA template (standardized at a concentration of $20 \mathrm{ng} / \mu \mathrm{L}$ ), $1 \times$ qPCR Master Mix (Kapa Biosystems, Resnova, Rome, Italy), $300 \mathrm{nM}$ of each primer, and $125 \mathrm{nM}$ of each probe (Eurofins Genomics, Milan, Italy). All the reactions included an internal amplification control (Exo IPC kit) (Eurogentec, Italy). PCR conditions comprised an enzyme activation step of $95^{\circ} \mathrm{C}$ for $5 \mathrm{~min}$, followed by 40 cycles: $95^{\circ} \mathrm{C}$ for $3 \mathrm{~s}$ (denaturation) and $60{ }^{\circ} \mathrm{C}$ for $30 \mathrm{~s}$ (annealing/extension/data acquisition). All the reference material used as reaction positive controls were provided by the European Union Reference Laboratory for E. coli (EU-RL VTEC). All stx-positive and eae-positive enrichment broths were screened for serogroups O26, O111, O103, O145 and O157 [40], while the st $x$-positive but eae-negative broths were screened also for the $\mathrm{O} 104$ serogroup following an additional protocol provided by the EURL VTEC [46]. All the serogroup Real-Time PCRs were done using the same reagent formulas and PCR conditions described above for the st $x$ and eae genes; only for serogroup $\mathrm{O} 103$ was the annealing/extension temperature lowered to $55^{\circ} \mathrm{C}$.

\subsection{Isolation of STEC Strains}

For STEC strain isolation, the stx-positive enrichment broths were cultured on Tryptone Bile X-Glucuronide (TBX) agar (Biolife Italiana srl, Milan, Italy) or, if screening of the enrichment broths indicated the presence of serogroup O26, were cultured also on Rhamnose MacConkey (RMAC) agar and incubated at $37^{\circ} \mathrm{C}$ for $18-24 \mathrm{~h}$. Then, of many colonies that phenotypically resembled E. coli, 
fifty were selected arbitrarily and re-analysed singly for the presence (or absence) of the stx and eae genes using Real-Time PCR. Based on the original enrichment broth results, STEC colonies were tested for one or more of the "big five" serogroups. Those st $x$-positive colonies that tested negative for the "big five", were then analysed for the O45, O55, O91, O113, O121, O128 and O146 serogroups, using a method provided by the EURL VTEC [46].

\subsection{Stx Subtyping}

The stx subtype of each STEC strain was identified using the PCR-based subtyping protocol of the Statens Serum Institut, WHO Collaborating Centre for Reference and Research on Escherichia and Klebsiella [9,11]. The PCR was done using the 2GFast Master mix (Resnova, Rome, Italy), $280 \mathrm{nM}$ of each primer (Eurofins, Milan, Italy) and $5 \mu \mathrm{L}$ of template DNA $(20 \mathrm{ng} / \mu \mathrm{L})$. Each reaction was adjusted to a final volume of $25 \mu \mathrm{L}$ in nuclease-free water. The annealing temperature was $66{ }^{\circ} \mathrm{C}$ for subtyping st $x 1 a-c, 62{ }^{\circ} \mathrm{C}$ for $s t x 2 a-c$, and $64^{\circ} \mathrm{C}$ for st $x 2 d-g$. Agarose gel electrophoresis was used to visualize the PCR products. A molecular weight marker (Euroclone S.p.a., Milan, Italy) was used to assign the molecular weight to amplicons produced. The samples were run in Tris-Borate-EDTA running buffer (VWR International Srl, Milan, Italy) at a constant voltage (100 V for the first ten minutes and $60 \mathrm{~V}$ until the end of electrophoresis). All Statens Serum Institut reference material used as reaction positive controls was provided through the EURL VTEC.

\section{Results}

\subsection{Real-Time PCR Screening of Enrichment Cultures, and Isolation of STEC Strains}

During initial Real-Time PCR screening of enrichment cultures, stx genes were detected in 20 $(8.4 \%)$ of the 239 samples. STEC was not isolated from 11 of these 20 st $x$-positive enrichment cultures, hence, based on the ISO/TS 13136:2012, in these samples only the "presumptive" presence of STEC could be determined. The eae gene was detected in eight of the eleven "presumptive" enrichment cultures, stx 1 in seven, and stx 2 in ten. One or more of the "big five" serogroups occurred singly, or in combination, in five enrichment cultures, as follows: O104 $(n=1), \mathrm{O} 103(n=1), \mathrm{O} 104+\mathrm{O} 111(n=1)$, $\mathrm{O} 26+\mathrm{O} 103+\mathrm{O} 157(n=2)$. For the six remaining "presumptive" STEC positive cultures, the serogroup was not identified. The regions of Italy from which "presumptive" positive STEC samples were obtained, are provided along with the sampling month in Table 1.

Table 1. STEC "presumptive" presence. Intimin (eae), Shiga-toxin st $x 1$ and st $x 2$ genes and serogroups detected in enrichment broth cultures obtained from fresh beef samples collected within 13 regions of Italy (2017).

\begin{tabular}{|c|c|c|c|c|c|c|c|}
\hline \multirow{2}{*}{$\begin{array}{l}\text { Region of } \\
\text { Italy }\end{array}$} & \multirow{2}{*}{$\begin{array}{c}\text { STEC } \\
\text { Presumptive } \\
\text { Presence (No) }\end{array}$} & \multirow{2}{*}{$\begin{array}{l}\text { Sampling } \\
\text { Month }\end{array}$} & \multirow{2}{*}{$\begin{array}{l}\text { Sample } \\
\text { ID }\end{array}$} & \multicolumn{3}{|c|}{ STEC Virulence Gene Profile } & \multirow{2}{*}{$\begin{array}{c}\text { E. coli } \\
\text { Serogroup }\end{array}$} \\
\hline & & & & eae & stx1 & $s t x 2$ & \\
\hline Abruzzo & 1 & May & 42696 & + & + & + & nd $^{1}$ \\
\hline Lazio & 2 & $\begin{array}{c}\text { September } \\
\text { October }\end{array}$ & $\begin{array}{l}78963 \\
82856\end{array}$ & & + & $\begin{array}{l}+ \\
+\end{array}$ & $\begin{array}{l}\text { nd }^{1} \\
\text { O104 }\end{array}$ \\
\hline Liguria & 1 & June & 51045 & + & + & + & O103 \\
\hline Lombardia & 4 & $\begin{array}{c}\text { August } \\
\text { September } \\
\text { September } \\
\text { November }\end{array}$ & $\begin{array}{l}64370 \\
72350 \\
75247 \\
96150\end{array}$ & $\begin{array}{l}+ \\
+ \\
+\end{array}$ & $\begin{array}{l}+ \\
+\end{array}$ & $\begin{array}{l}+ \\
+ \\
+ \\
+\end{array}$ & $\begin{array}{c}\text { nd }^{1} \\
\text { O104-O111 } \\
\text { O26-O103-O157 } \\
\text { nd }^{1}\end{array}$ \\
\hline Marche & 1 & November & 97189 & + & & + & nd $^{1}$ \\
\hline Puglia & 1 & July & 57025 & + & + & & nd $^{1}$ \\
\hline Veneto & 1 & October & 87734 & + & + & + & O26-O103-O157 \\
\hline
\end{tabular}


Twenty STEC strains were isolated from nine of the 20 st $x$-positive enrichment cultures, hence the samples are classified as STEC "presence". The STEC-positive samples were obtained from the regions of Calabria (eae $+s t x 1+s t x 2 ; n=1)$, Campania $(s t x 2 ; n=1)$, Lazio (eae $+s t x 1+s t x 2$ and st $x 1$ + st $x 2 ; n=2)$, Liguria $(s t x 1+s t x 2 ; n=1)$, Lombardia $(s t x 2 ; n=1)$ and Veneto (eae + st $x 1+s t x 2 ; n=3)$. Three different serogroups were identified amongst the 20 strains isolated: O91 $(n=5), \mathrm{O} 113(n=2)$, and $\mathrm{O} 157(n=1)$. The remaining 12 STEC strains tested negative for all the serogroups analysed $(\mathrm{O} 26$, O45, O55, O91, O103, O104, O111, O113, O121, O128, O145, O146 and O157).

\subsection{Stx Subtyping}

Subtyping of the stx genes detected in the 20 STEC isolates, displayed various st $x 1$ and st $x 2$ subtype profiles. Strains belonging to serogroup O91 $(n=5)$ carried five different virulence gene profiles (eae + stx $1 a ;$ eae + stx $1 c ;$ stx $2 c ;$ eae + stx $1 a+s t x 1 c+s t x 2 c ; e a e+s t x 1 a+s t x 1 c+s t x 2 c+s t x 2 d)$. Two O113 isolates were eae-negative and contained subtypes st $x 2 c$ and $s t x 2 c+s t x 2 d$, respectively. One O157 strain was eae-positive and comprised st $x$ subtypes st $x 1 a+s t x 2 c+s t x 2 d$. Twelve STEC isolates tested negative to all 13 serogroups analysed (nd, Table 2); amongst these isolates various combinations of eae and stx subtypes were detected, with stx $2 c$ found most frequently, followed by stx $2 d, s t x 2 b$ and st $x 2 a$, respectively. Finally, subtypes stx $1 d$, stx $2 e, s t x 2 f$ and st $x 2 g$ were not detected in any of the 20 STEC isolates obtained (Table 2).

\subsection{Discussion}

Cattle are considered a major reservoir for virulent strains of Shiga toxin-producing Esherichia coli (STEC) and the most important source of human infections through the consumption of contaminated beef products. The aim of this study was to identify and characterise the STEC strains found to occur in fresh beef obtained from 13 regions in Italy. A culture method involving selective and non-selective media, and following an initial enrichment step, was used to isolate STEC strains $[1,47]$. Specific PCR assays were used to identify pathogenicity factors (eae and stx genes), serogroups, and stx subtypes $[1,17,40,48,49]$. Initial enrichment yielded $20(8.4 \%)$ st $x$-positive cultures, while STEC strains were only isolated from nine cultures. The failure to isolate STEC from a stx-positive enrichment culture has been reported upon previously [21,50-52]. To isolate STEC from food can be challenging because the number of STEC cells are likely to be low; other hurdles include sublethal cell injury, or cell growth suppressed in the presence of a large population of competing microflora $[4,21,53]$. For these reasons, enrichment cultures are essential to augment sensitivity, thereby promoting the isolation of STEC strains needed to confirm the presence of the stx genes in the live cell, while excluding the presence of free DNA or free prophages in the cultures [28]. Recently, various authors have reported the reduced sensitivity of mTSB enrichment broths supplemented with novobiocin $(16 \mathrm{mg} / \mathrm{L})$, suggesting that a decrease in novobiocin concentration might improve detection of O111 and other non-O157 serogroups [41-44]. While it is possible that reduced concentrations of novobiocin facilitate the isolation of non-O157 serogroups, 19 of the 20 isolates obtained represented non-O157 STEC strains. 
Table 2. Subtyping of Shiga-toxin stx 1 and stx 2 genes and serogroups associated with STEC strains isolated from fresh beef samples collected within 13 regions of Italy (2017).

\begin{tabular}{|c|c|c|c|c|c|c|c|c|c|c|c|}
\hline \multirow{2}{*}{ Region of Italy } & \multirow{2}{*}{$\begin{array}{c}\text { Samples } \\
\text { Positive (No) }\end{array}$} & \multirow{2}{*}{$\begin{array}{l}\text { Sampling } \\
\text { Month }\end{array}$} & \multirow{2}{*}{ Strain ID } & \multicolumn{6}{|c|}{ stx Subtypes ${ }^{1}$} & \multirow{2}{*}{ eae } & \multirow{2}{*}{ Serogroup } \\
\hline & & & & stx $1 a$ & stx $1 c$ & $s t x 2 a$ & $s t x 2 b$ & $s t x 2 c$ & $s t x 2 d$ & & \\
\hline \multirow{4}{*}{ Calabria } & \multirow{4}{*}{1} & \multirow{4}{*}{ November } & $94200-01$ & + & & & & & & + & O91 \\
\hline & & & $94200-02$ & & + & & & & & + & O91 \\
\hline & & & $94200-03$ & + & + & & & + & + & + & $\mathrm{nd}^{2}$ \\
\hline & & & $94200-04$ & + & + & & & + & + & + & O91 \\
\hline Campania & 1 & December & $107402-01$ & & & & & + & & & nd $^{2}$ \\
\hline \multirow{7}{*}{ Lazio } & \multirow{7}{*}{2} & \multirow{3}{*}{ June } & $50231-01$ & & & & & + & & & O91 \\
\hline & & & 50231-02 & + & & & & + & + & + & O157 \\
\hline & & & 50231-03 & & & & & + & & & $\mathrm{O} 113$ \\
\hline & & \multirow{4}{*}{ November } & $107400-01$ & & & & & + & + & & O113 \\
\hline & & & $107400-02$ & & + & & + & & & & $\mathrm{nd}^{2}$ \\
\hline & & & $107400-03$ & + & & & & + & + & & nd $^{2}$ \\
\hline & & & $107400-04$ & & & & & + & + & & $\mathrm{nd}^{2}$ \\
\hline Liguria & 1 & December & 104076-01 & + & + & + & + & & & & nd $^{2}$ \\
\hline Lombardia & 1 & July & 58927-01 & & & & + & + & & & $\mathrm{nd}^{2}$ \\
\hline \multirow{6}{*}{ Veneto } & \multirow{6}{*}{3} & March & 27847-01 & & & & + & & & & nd $^{2}$ \\
\hline & & \multirow{2}{*}{ March } & $22774-01$ & & & & & + & + & & nd $^{2}$ \\
\hline & & & $22774-02$ & & & & & + & & & nd $^{2}$ \\
\hline & & \multirow{3}{*}{ November } & $94197-01$ & + & + & & & + & & + & O91 \\
\hline & & & $94197-02$ & + & + & & & + & & + & nd $^{2}$ \\
\hline & & & $94197-03$ & + & + & & & + & + & + & nd $^{2}$ \\
\hline
\end{tabular}

${ }^{1}$ stx subtypes included stx1a- $d$ and $s t x 2 a-g$; subtypes stx1d, stx $2 e$, st $x 2 f$ and $s t x 2 g$, were not detected in any of the isolated STEC strains. ${ }^{2}$ nd (not detemined): strains that tested negative to all serogroups analysed (O26, O45, O55, O91, O103, O104, O111, O113, O121, O128, O145, O146 and O157). 
In this study, overall STEC contamination in beef was 3.8\%, a prevalence rate that agrees only partly with rates obtained previously in Italy. A frequency rate of $0.42 \%$ for STEC O157 matches that obtained during a nationwide survey conducted by Conedera et al. [54] and who reported STEC in four $(0.43 \%)$ of 931 minced beef samples. These were screened only for serogroup O157. In the region of Piemonte, Rantsiou et al. [55] found six (5.9\%) STEC strains in 101 mixed meat products using a method developed in-house. In the Emilia Romagna region, Bardasi et al. [56], following the ISO/TS 13136:2012 protocol, demonstrated an STEC presence in four $(0.6 \%)$ of 689 meat samples (representing pork, bovine and poultry). In a more recent study, the same ISO protocol was used to test 675 pork samples (comprising both fresh and dried products) collected in the Umbria and Marche regions of Italy [57]; these authors reported the presumptive presence of st $x$-genes in $2.8 \%$ of the products, but were unable to isolate any STEC strains. The discrepant STEC prevalence rates obtained may find causes in various factors, including geographic compartmentalization of the E. coli population amongst food animals, laboratory techniques and protocols employed [54,55], and the wide range in meat products analysed. According to EFSA, in Europe, the overall presence of STEC in 18,975 food samples assayed was $2.5 \%$, the highest proportion found in meat, particularly that from small ruminants [34]. In Switzerland, Fantelli et al. reported the presence of STEC in $2.3 \%$ of 211 minced beef samples tested [58]; in France, $4 \%$ of 411 beef samples were STEC positive [59]. Our STEC prevalence rates are comparable to some of those obtained for beef previously in Europe [34,58,59].

Real-Time PCR, based on the O-antigen synthesis genes ( $w z x$ and $w z y$ ), is widely used to serogroup STEC strains [60]. However, the Real-Time PCR methods currently used do not cover all known serogroups, hence many serogroups to which a STEC strain may belong remain unidentified [33]; consequently, 12 of our 20 STEC strains could not be identified to serogroup. While serogroups and serotypes are not virulence factors and not predictive of a virulence profile, they nevertheless remain useful for conducting surveillance and for investigating outbreaks [61]. Serogroups O26, O103, O104, O111 and O157, along with the eae and st $x 2$ virulence genes, were detected in 11 enrichment broths; the failure to isolate STEC strains from these 11 broths is the reason why the corresponding samples were classified as "presumptive" positive. The potential risk to human health that "presumptives" represent, means the responsible authorities must continue to monitor for STEC.

An association between Stx subtype and severity of disease in humans has been observed [51,62]. In this study, 20 STEC strains were isolated from nine beef samples and carried st $x$ subtypes in various combinations. The st $x 1$ subtypes detected were stx $1 a$ and stx $1 c$. The Stx1a toxin subtype is often produced by strains that are eae-positive and known to cause severe disease in man [32]. In this study, nine STEC strains, either eae-positive or eae-negative, had st $x 1 a$ alone or in combination with st $x 1 c$ or st $x 2 a, s t x 2 b, s t x 2 c$ and st $x 2 d$. The Stx1c toxin subtype is reported mainly in eae-negative strains causing mild infections [63]; we found stx1c both in identified (serogroup 091) and unidentified serogroups that were eae-positive (Table 2). With regard to toxin type Stx2, the subtypes st $x 2 a$, st $x 2 c$ and st $x 2 d$ have been linked to HC and HUS in humans $[11,16]$. In this study STEC isolates carrying st $x 2 c$ were the st $x$ subtypes most commonly found, followed by st $2 d$ and st $x 2 b$. Subtype st $x 2 a$ was identified in only one eae-negative strain and occurred in combination with st $x 1 a$, st $x 1 c$ and st $x 2 b$. Of the eight eae-positive STEC strains obtained, four belonged to serogroup O91, one to O157, while three represented unidentified serogroups. Two strains of $\mathrm{O} 113$ and one of 091 were eae-negative; the nine remaining strains were not identified to serogroup (Table 2). Contrary to other reports [64], we found four O91 STEC strains to be eae-positive; this finding is unusual and we cannot explain it satisfactorily. Subtype stx $2 d$ was found in eight STEC strains, of which four were eae-negative, while the other four were eae-positive; the latter group included a strain $\mathrm{O} 157$ that was also stx1a- and st $x 2 c$-positive. The st $x 2 d$ subtype is usually associated with eae-negative strains and severe disease in humans [65]; recently, in Spain, Sanchez et al. [66] reported upon a O157:H7 strain that was eaeand st $2 d$-positive and isolated from a 2-year-old child with BD. This unusual virulence combination, though rare, has been reported also from several HUS-affected patients in France and separately involving STEC O26:H11 [67] and STEC O80:H2 [68]. 


\section{Conclusions}

In Italy, the isolation of STEC strains from fresh meat samples signals the recurring threat that beef, consumed either undercooked or raw, poses to human health. The variety of stx types and subtypes and multiple STEC serogroups detected, are amongst those found elsewhere in the world and where, in humans, they have been demonstrated to be involved in severe diseases, such as BD, HC and HUS. The presence in meat of potentially harmful STEC strains emphasizes the importance, during harvest, of implementing additional measures to reduce contamination risk. Linked to this, an efficient surveillance strategy for STECs in retail foodstuffs, remains a national priority. The laboratory diagnostic protocols needed to isolate and accurately identify STEC strains are laborious, expensive, and time-consuming. However, they continue to remain pivotal to assessing the strain of pathogenic E. coli involved, and for identifying the possible source of infection. This knowledge is needed to enable the competent authorities to respond precisely and rapidly. Improvements to current isolation techniques, and the validation and standardization of molecular protocols, remain a matter of urgency. It is foreseen that in the future new high-power methodologies, such as Next-Generation Sequencing (NGS), will become more widely utilised and that these will lead to further improvements in the currently used standards for diagnosing STEC in foods.

Author Contributions: Conceptualization, P.D.S. and B.M.V.; Methodology, B.M.V., F.T., L.D.S., F.D.G. and S.L.; Data curation, B.M.V.; Writing—original draft preparation, B.M.V.; Writing—review and editing, P.D.S.; Supervision, P.D.S.; project administration, S.B.; funding acquisition, S.B.

Funding: This research received no external funding.

Acknowledgments: The authors thank the staff of the Laboratory of Food Microbiology (Istituto Zooprofilattico Sperimentale Lazio e Toscana "M. Aleandri", Italy) for the collaboration provided to this study. The authors also wish to thank the National Reference Laboratory for Antimicrobial Resistance (Istituto Zooprofilattico Sperimentale Lazio e Toscana "M. Aleandri", Italy) for kindly providing the samples used in this study. Special thanks to Rudy Meiswinkel.

Conflicts of Interest: The authors declare no conflict of interest.

\section{References and Note}

1. Bonardi, S.; Alpigiani, I.; Tozzoli, R.; Vismarra, A.; Zecca, V.; Greppi, C. Shiga toxin-producing Escherichia coli O157, O26 and O111 in cattle faeces and hides in Italy. Vet. Rec. Open 2015, 2, 1-9. [CrossRef] [PubMed]

2. Melton-Celsa, A.R. Shiga Toxin (STx) Classification, Structure, and Function. Microbiol. Spectr. 2014, 2, 1-21. [CrossRef] [PubMed]

3. Bertin, Y.; Boukhors, K.; Pradel, N.; Livrelli, V.; Martin, C. Stx2 Subtyping of Shiga Toxin-Producing Escherichia coli Isolated from Cattle in France: Detection of a New Stx2 Subtype and Correlation with Additional Virulence Factors. J. Clin. Microbiol. 2001, 39, 3060-3065. [CrossRef]

4. Farrokh, C.; Jordan, K.; Auvray, F.; Glass, K.; Oppegaard, H.; Raynaud, S.; Thevenot, D.; Condron, R.; De Reu, K.; Govaris, A.; et al. Review of Shiga-toxin producing Escherichia coli and their significance in dairy production. Int. J. Food Microbiol. 2013, 162, 190-212. [CrossRef] [PubMed]

5. Hussein, H.S. Prevalence and pathogenicity of Shiga toxin-producing Escherichia coli in beef cattle and their products. J. Anim. Sci. 2014, 85, E63-E72. [CrossRef] [PubMed]

6. Brett, K.N.; Ramachandran, V.; Hornitzky, M.A.; Bettelheim, K.A.; Walker, M.J.; Djordjevic, S.P. stx $x_{1 \mathrm{c}}$ is the most common Shiga toxin 1 subtype among Shiga toxin-producing Escherichia coli isolates from sheep but not among isolates from cattle. J. Clin. Microbiol. 2003, 41, 926-936. [CrossRef] [PubMed]

7. Hofer, E.; Cernela, N.; Stephan, R. Shiga Toxin Subtypes Associated with Shiga Toxin-Producing Escherichia coli Strains Isolated from Red Deer, Roe Deer, Chamois, and Ibex. Foodborne Pathog Dis. 2012, 9, 792-795. [CrossRef]

8. Mora, A.; López, C.; Dhabi, G.; López-Beceiro, A.M.; Fidalgo, L.E.; Díaz, E.A.; Martínez-Carrasco, C.; Mamani, R.; Herrera, A.; Blanco, J.E.; et al. Seropathotypes, Phylogroups, Stx Subtypes, and Intimin Types of Wildlife-Carried, Shiga Toxin-Producing Escherichia coli Strains with the Same Characteristics as Human-Pathogenic Isolates. Appl. Environ. Microbiol. 2012, 78, 2578-2585. [CrossRef] 
9. Scheutz, F.; Teel, L.D.; Beutin, L.; Piérard, D.; Buvens, G.; Karch, H.; Mellmann, A.; Caprioli, A.; Tozzoli, A.; Morabito, S.; et al. Multicenter evaluation of a sequence-based protocol for subtyping Shiga toxins and standardizing Stx nomenclature. J. Clin. Microbiol. 2012, 50, 2951-2963. [CrossRef]

10. Bielaszewska, M.; Prager, R.; Zhang, W.; Friedrich, A.W.; Mellmann, A.; Tschäpe, H.; Karch, H. Chromosomal dynamism in progeny of outbreak-related sorbitol-fermenting enterohemorrhagic Escherichia coli O157: NM. Appl. Environ. Microbiol. 2006, 72, 1900-1909. [CrossRef]

11. Persson, S.; Olsen, K.E.; Ethelberg, S.; Scheutz, F. Subtyping method for Escherichia coli Shiga toxin (Verocytotoxin) 2 variants and correlation to clinical manifestations. J. Clin. Microbiol. 2007, 45, 2020-2024. [CrossRef] [PubMed]

12. Hussein, H.S.; Bollinger, L.M. Prevalence of Shiga toxin-producing Escherichia coli in beef cattle. J. Food Prot. 2005, 68, 2224-2241. [CrossRef] [PubMed]

13. Schmidt, H.; Scheef, J.; Morabito, S.; Caprioli, A.; Wieler, L.H.; Karch, H. A new Shiga toxin 2 variant (Stx2f) from Escherichia coli isolated from pigeons. Appl. Environ. Microbiol. 2000, 66, 1205-1208. [CrossRef] [PubMed]

14. Leung, P.H.; Yam, W.C.; Ng, W.W.; Peiris, J.S. The prevalence and characterization of verotoxin-producing Escherichia coli isolated from cattle and pigs in an abattoir in Hong Kong. Epidemiol. Infect. 2001, 126, 173-179. [CrossRef]

15. Eklund, M.; Leino, K.; Siitonen, A. Clinical Escherichia coli strains carrying stx genes: Stx variants and stx-positive profiles. J. Clin. Microbiol. 2002, 40, 4585-4593. [CrossRef] [PubMed]

16. Friedrich, A.W.; Bielaszewska, M.; Zhang, W.; Pulz, M.; Kuczius, T.; Ammon, A.; Karch, H. Escherichia coli harboring Shiga toxin 2 gene variants: Frequency and association with clinical symptoms. J. Infect. Dis. 2002, 185, 74-84. [CrossRef] [PubMed]

17. Caprioli, A.; Morabito, S.; Brugere, H.; Oswald, E. Enterohaemorrhagic Escherichia coli: Emerging issues on virulence and modes of transmission. Vet. Res. 2005, 36, 289-311. [CrossRef] [PubMed]

18. Friesema, I.H.M.; Keijzer-Veen, M.G.; Koppejan, M.; Schipper, H.S.; van Griethuysen, A.J.; Heck, M.E.O.; van Pelt, W. Hemolytic Uraemic Syndrome associated with Escherichia coli O8:H19 and shiga toxin $2 \mathrm{f}$ gene. Emerg. Infect. Dis. 2015, 79, 1329-1337.

19. Grande, L.; Michelacci, V.; Giugliacci, F.; Badouei, M.A.; Schlager, S.; Minelli, F.; Caprioli, A.; Morabito, S. Whole-genome Characterization and strain comparison of VT2f-producing Escherichia coli causing haemolytic uraemic syndrome. Emerg. Infect. Dis. 2016, 22, 2078-2086. [CrossRef]

20. Kaper, J.B.; Nataro, J.P.; Mobley, H.L.T. Pathogenic Escherichia coli. Nat. Rev. Microbiol. 2004, 2, $123-140$. [CrossRef]

21. Nobili, G.; Franconieri, I.; La Bella, G.; Basanisi, M.G.; La Salandra, G. Prevalence of Verocytotoxigenic Escherichia coli strains isolated from raw beef in southern Italy. Int. J. Food Microbiol. 2017, 257, 201-205. [CrossRef]

22. Duffy, G.; Burgess, C.M.; Bolton, D.J. A review of factors that affect the transmission and survival of verocytotoxigenic Escherichia coli in the European farm to fork chain. Meat Sci. 2014, 97, 375-383. [CrossRef]

23. Caprioli, A.; Maugliani, A.; Michelacci, V.; Morabito, S. Molecular typing of verocytotoxin-producing E. coli (VTEC) strains isolated from food, feed and animals: State of play and standard operating procedures for pulsed field gel electrophoresis (PFGE) typing, profiles interpretation and curation. EFSA Support. Publ. 2014, 704, 1-55.

24. Boerlin, P.; McEwen, S.A.; Boerlin-Petzold, F.; Wilson, J.B.; Johnson, R.P.; Gyles, C.L. Associations between Virulence Factors of Shiga Toxin-Producing Escherichia coli and Disease in Humans. J. Clin. Microbiol. 1999, 37, 497-503.

25. Beutin, L.; Martin, A. Outbreak of Shiga Toxin-Producing Escherichia coli (STEC) O104:H4 Infection in Germany Causes a Paradigm Shift with Regard to Human Pathogenicity of STEC Strains. J. Food Prot. 2012, 75, 408-418. [CrossRef]

26. Bettelheim, K.A. The non-O157 Shiga-toxigenic (verocytotoxigenic) Escherichia coli: Under-rated pathogens. Crit. Rev. Microbiol. 2007, 33, 67-87. [CrossRef]

27. Food and Agriculture Organization of the United Nations (FAO); World Health Organization (WHO). Shiga Toxin-Producing Escherichia coli (STEC) and Food: Attribution, Characterization, and Monitoring: Report; Microbiological Risk Assessment Series; FAO: Rome, Italy; WHO: Geneva, Switzerland, 2018. 
28. European Food Safety Authority. Scientific opinion on VTEC-seropathotype and scientific criteria regarding pathogenicity assessment. EFSA J. 2013, 11, 1-106.

29. Commission Regulation (EU) No 209/2013. 2013 of 11 March 2013 amending Regulation (EC) No 2073/2005 as regards microbiological criteria for sprouts and the sampling rules for poultry carcases and fresh poultry meat. Available online: http:/ / data.europa.eu/eli/reg/2013/209/oj (accessed on 12 March 2013).

30. Kiranmayi, Ch.B.; Krishnaiah, N.; Mallika, E.N. Escherichia coli O157:H7-An Emerging Pathogen in foods of Animal Origin. Vet. World. 2010, 3, 382-389. [CrossRef]

31. Centre for Disease Prevention and Control (CDC). National Enteric Disease Surveillance: Shiga Toxin-Producing Escherichia coli (STEC) Annual Report, 2015; CS 282919-A; CDC: Atlanta, GA, USA, 2017.

32. Brooks, J.T.; Sowers, E.G.; Wells, J.G.; Greene, K.D.; Griffin, P.M.; Hoekstra, R.M.; Strockbine, N.A. Non-O157 Shiga toxin-producing Escherichia coli infections in the United States, 1983-2002. J. Infect. Dis. 2005, 192, 1422-1429. [CrossRef]

33. European Food Safety Authority (EFSA); European Centre for Disease Prevention and Control (ECDC). The European Union summary report on trends and sources of zoonoses, zoonotic agents and food-borne outbreaks in 2015. EFSA J. 2016, 14, 4634.

34. European Food Safety Authority (EFSA); European Centre for Disease Prevention And Control (ECDC). The European Union summary report on trends and sources of zoonoses, zoonotic agents and food-borne outbreaks in 2016. EFSA J. 2017, 15, 5077.

35. European Food Safety Authority. Technical specifications on randomised sampling for harmonized monitoring of antimicrobial resistance in zoonotic and commensal bacteria. EFSA J. 2014, 12, 3686.

36. Arthur, T.M.; Bosilevac, J.M.; Nou, X.; Shackelford, S.D.; Wheeler, T.L.; Kent, M.P.; Jaroni, D.; Pauling, B.; Allen, D.M.; Koohmaraie, M. Escherichia coli O157 prevalence and enumeration of aerobic bacteria, Enterobacteriaceae, and Escherichia coli $\mathrm{O} 157$ at various steps in commercial beef processing plants. J. Food Prot. 2004, 67, 658-665. [CrossRef]

37. Buncic, S.; Nychas, G.J.; Lee, M.R.; Koutsoumanis, K.; Hébraud, M.; Desvaux, M.; Antic, D. Microbial pathogen control in the beef chain: Recent research advances. Meat Sci. 2014, 97, 288-297. [CrossRef]

38. No. 1441/2007 of 5 December 2007 Amending Regulation (EC) No 2073/2005 on Microbiological Criteria for Foodstuffs. OJ L 322, 7.12.2007, p 12-29. Available online: http:/ / data.europa.eu/eli/reg/2007/1441/oj (accessed on 23 December 2014).

39. Commission Regulation (EC), No. 2073/2005 of 15 November 2005 on Microbiological Criteria for Foodstuffs. OJ L 338, 22.12.2005, p 1-26. Available online: http:/ / data.europa.eu/eli/reg/2005/2073/oj (accessed on 23 December 2014).

40. International Organization for Standardization, ISO/TS 13136:2012, 2012. Microbiology of food and animal feed-Real-time polymerase chain reaction (PCR)-based method for the detection of food-borne pathogens - Horizontal method for the detection of Shiga toxin-producing Escherichia coli (STEC) and the determination of O157, O111, O26, O103 and O145 serogroups.

41. Amagliani, G.; Rotundo, L.; Carlonia, E.; Omiccioli, E.; Magnania, M.; Brandia, G.; Fratamico, P. Detection of Shiga toxin-producing Escherichia coli (STEC) in ground beef and bean sprouts: Evaluation of culture enrichment conditions. Food Res. Int. 2018, 103, 398-405. [CrossRef]

42. Fratamico, P.M.; Wasilenko, J.L.; Garman, B.; Demarco, D.R.; Varkey, S.; Jensen, M.; Rhoden, K.; Tice, G. Evaluation of a multiplex real-time PCR method for detecting shiga toxin-producing Escherichia coli in beef and comparison to the U.S. Department of Agriculture Food Safety and Inspection Service Microbiology laboratory guidebook method. J. Food Prot. 2014, 77, 180-188. [CrossRef]

43. Fratamico, P.M.; Bagi, L.K.; Cray, W.C., Jr.; Narang, N.; Yan, X.; Medina, M.; Liu, Y. Detection by multiplex real-time polymerase chain reaction assays and isolation of Shiga toxin-producing Escherichia coli serogroups O26, O45, O103, O111, O121, and O145 in ground beef. Foodborne Pathog. Dis. 2011, 8, 601-607. [CrossRef]

44. Vimont, A.; Delignette-Muller, M.-L.; Vernozy-Rozand, C. Supplementation of enrichment broths by novobiocin for detecting Shiga toxin-producing Escherichia coli from food: A controversial use. Lett. Appl. Microbiol. 2007, 44, 326-331. [CrossRef]

45. 2013/652/EU: Commission Implementing Decision of 12 November 2013 on the monitoring and reporting of antimicrobial resistance in zoonotic and commensal bacteria (notified under document C(2013) 7145) Text with EEA relevance. OJ L 303, 14.11.2013, p 26-39. Available online: http:/ / data.europa.eu/eli/dec_impl/ 2013/652/oj (accessed on 12 November 2013). 
46. European Union Reference Laboratory for E. coli.. Identification of the STEC serogroups mainly associated with human infections by Real-Time PCR amplification of O-associated genes. Available online: http: / / old.iss.it/vtec/index.php?lang=2\&anno=2014\&tipo=3 (accessed on 25 March 2018).

47. Wang, L.; Wakushima, M.; Aota, T.; Yoshida, Y.; Kita, T.; Maehara, T. Specific properties of enteropathogenic Escherichia coli isolates from diarrheal patients and comparison to strains from foods and faecal specimens from cattle, swine, and healthy carriers in Osaka City, Japan. Appl. Environ. Microbiol. 2013, 79, 1232-1240. [CrossRef]

48. Paddock, Z.; Shi, X.; Bai, J.; Nagaraja, T.G. Applicability of a multiplex PCR to detect O26, O45, O103, O111, O121, O145, and O157 serogroups of Escherichia coli in cattle feces. Vet. Microbiol. 2012, 156, 381-388. [CrossRef]

49. Scheutz, F.; Strockbine, N.A. Escherichia. In Bergey's Manual of Systematic Bacteriology, 2nd ed.; Garrity, G.M., Brenner, D.J., Krieg, N.R., Staley, J.T., Eds.; Springer: New York, NY, USA, 2005; Volume 2, pp. 607-624. ISBN 978-0-387-29298-4.

50. Meng, Q.; Bai, X.; Zhao, A.; Lan, R.; Du, H.; Wang, T.; Shi, C.; Yuan, X.; Bai, X.; Ji, S.; et al. Characterization of Shiga toxin-producing Escherichia coli from healthy pigs in China. BMC Microbiol. 2014, 14, 5. [CrossRef]

51. Bai, X.; Wang, H.; Xin, Y.; Wei, R.; Tang, X.; Zhao, A.; Sun, H.; Wang, Z.; Wang, J.; Xu, Y.; et al. Prevalence and characteristics of Shiga toxin-producing Escherichia coli isolated from retail raw meats in China. Int. J. Food Microbiol. 2015, 200, 31-38. [CrossRef]

52. Quiros, P.; Martinez-Castillo, A.; Muniesa, M. Improving detection of Shiga toxin-producing Escherichia coli by molecular methods by reducing the interference of free Shiga toxin-encoding bacteriophages. Appl. Environ. Microbiol. 2015, 81, 415-421. [CrossRef]

53. Brusa, V.; Aliverti, V.; Aliverti, F.; Ortega, E.E.; De la Torre, J.H.; Linares, L.H.; García, P.P. Shiga toxin-producing Escherichia coli in beef retail markets from Argentina. Front. Cell. Infect. Microbiol. 2012, 2, 171. [CrossRef]

54. Conedera, G.; Dalvit, P.; Martini, M.; Galiero, G.; Gramaglia, M.; Goffredo, E.; Loffredo, G.; Morabito, S.; Ottaviani, D.; Paterlini, F.; et al. Verocytotoxin-producing Escherichia coli O157 in minced beef and dairy products in Italy. Int J. of Food Microb. 2004, 96, 67-73. [CrossRef]

55. Rantsiou, K.; Alessandria, V.; Cocolin, L. Prevalence of Shiga toxin-producing Escherichia coli in food products of animal origin as determined by molecular methods. Int. J. Food Microb. 2012, 154, 37-43. [CrossRef]

56. Bardasi, L.; Taddei, R.; Nocera, L.; Ricchi, M.; Merialdi, G. Shiga toxin-producing Escherichia coli in meat and vegetable products in Emilia Romagna Region, years 2012-2013. Ital. J. Food Saf. 2015, 4, 4511. [CrossRef]

57. Ercoli, L.; Farneti, S.; Zivaco, A.; Mencaroni, G.; Blasi, G.; Striano, G.; Scuota, S. Prevalence and characteristics of verotoxigenic Escherichia coli strains isolated from pigs and pork products in Umbria and Marche regions of Italy. Int J. Food Microbiol. 2016, 232, 7-14. [CrossRef]

58. Fantelli, K.; Stephan, R. Prevalence and characteristics of shiga toxin-producing Escherichia coli and Listeria monocytogenes strains isolated from minced meat in Switzerland. Int J. Food Microbiol. 2001, 70, 63-69. [CrossRef]

59. Pradel, N.; Livrelli, V.; De Champs, C.; Palcoux, J.B.; Reynaud, A.; Scheutz, F.; Sirot, J.; Joly, B.; Forestier, C. Prevalence and characterization of Shiga toxin-producing Escherichia coli isolated from cattle, food, and children during a one-year prospective study in France. J. Clin. Microbiol. 2000, 38, 1023-1031.

60. Lin, A.; Sultan, O.; Lau, H.K.; Wong, E.; Hartman, G.; Lauzon, C.R. O serogroup specific real time PCR assays for the detection and identification of nine clinically relevant non-O157 STECs. Food Microbiol. 2011, 28, 478-483. [CrossRef]

61. Conrad, C.C.; Stanford, K.; McAllister, T.A.; Thomas, J.; Reuter, T. Further development of sample preparation and detection methods for $\mathrm{O} 157$ and the top 6 non-O157 STEC serogroups in cattle feces. J. Microbiol. Methods 2014, 105, 22-30. [CrossRef]

62. Bosilevac, J.M.; Koohmaraie, M. Prevalence and characterization of non-O157 shiga toxin-producing Escherichia coli isolates from commercial ground beef in the United States. Appl. Environ. Microbiol. 2011, 77, 2103-2112. [CrossRef]

63. Friedrich, A.W.; Borell, J.; Bielaszewska, M.; Fruth, A.; Tschäpe, H.; Karch, H. Shiga toxin 1c-producing Escherichia coli strains: Phenotypic and genetic characterization and association with human disease. J. Clin. Microb. 2003, 41, 2448-2453. [CrossRef] 
64. Feng, P.C.H.; Delannoy, S.; Lacher, D.W.; Bosilevac, J.M.; Fach, P.; Beutin, L. Shiga toxin-producing serogroup O91 Escherichia coli strains isolated from food and environmental samples. Appl. Environ. Microbiol. 2017, 83, e01231-17. [CrossRef]

65. Bielaszewska, M.; Friedrich, A.W.; Aldick, T.; Schürk-Bulgrin, R.; Karch, H. Shiga toxin activatable by intestinal mucus in Escherichia coli isolated from humans: Predictor for a severe clinical outcome. Clin Infect. Dis. 2006, 43, 1160-1167. [CrossRef]

66. Sánchez, S.; Llorente, M.; Herrera-León, L.; Ramiro, R.; Nebreda, S.; Remacha, M.; Herrera-León, S. Mucus-Activatable Shiga Toxin Genotype stx2d in Escherichia coli O157:H7. Emerg. Infect. Dis. 2017, 23, 1431-1433. [CrossRef]

67. Delannoy, S.; Mariani-Kurkdjian, P.; Bonacorsi, S.; Liguori, S.; Fach, P. Characteristics of emerging human-pathogenic Escherichia coli O26:H11 strains isolated in France between 2010 and 2013 and carrying the stx2d gene only. J. Clin. Microbiol. 2015, 53, 486-492. [CrossRef]

68. Mariani-Kurkdjian, P.; Lemaître, C.; Bidet, P.; Perez, D.; Boggini, L.; Kwon, T.; Bonacorsi, S. Haemolyticuraemic syndrome with bacteraemia caused by a new hybrid Escherichia coli pathotype. New Microbes New Infect. 2014, 2, 127-131. [CrossRef]

(C) 2018 by the authors. Licensee MDPI, Basel, Switzerland. This article is an open access article distributed under the terms and conditions of the Creative Commons Attribution (CC BY) license (http:/ / creativecommons.org/licenses/by/4.0/). 